Mitteilungen der Österreichischen Geographischen Gesellschaft, 158. Jg. (Jahresband), Wien 2016, S. 401-419

\title{
BUCHBESPRECHUNGEN BOoK REVIEWS
}

\author{
Berger Frank (2015), Julius Payer. Die unerforschte Welt der Berge und des Eises. Bergpio- \\ nier - Polarfahrer - Historienmaler. Innsbruck - Wien, Tyrolia. 267 S., zahlreiche z.T. farbige \\ Abbildungen. ISBN 978-3-7022-3441-6.
}

Das Buch von Frank Berger stellt die erste umfangreiche Biographie über Julius PAYER (18421915) dar. PAYER zählt ohne Zweifel zu den bedeutendsten österreichischen Entdeckungsreisenden des 19. Jhs. Der Offizier, Alpinist und Historienmaler leitete zum Beispiel zusammen mit Carl WeYPRECHT (1838-1881) die Österreichisch-Ungarische Nordpolexpedition (1872-1874) und entdeckte dabei unter anderem das Franz-Josephs-Land [Zemlja Franca-Iosifa]. In insgesamt 19 Kapiteln beschreibt Frank BERGER alle Facetten von PAYERs Leben: seine Familie, seine Militärlaufbahn, seine Forschungen im alpinen Bereich, seine Polarfahrten und seine Karriere als Künstler. Den größten Raum nehmen dabei PAYERs Forschungsreisen in den arktischen Bereich ein. Unzählige, zum großen Teil farbige und qualitativ hochwertige Abbildungen, die von Portraits über Karten bis hin zu Gemälden aus der zweiten Hälfte des 19. Jhs. und heutigen Fotos reichen, komplettieren die vielen in dem Buch enthaltenen Informationen. Texte und Bilder vermitteln ein eindrucksvolles Bild von PAYERs wissenschaftlicher Laufbahn und dessen Leistungen während seiner Polarfahrten. Erwähnenswert sind auch BERGERs Schilderungen von PAYERs Tätigkeit als Maler, was bis heute noch keine Beachtung gefunden hat.

Trotz dieser vielen im Buch enthaltenen Informationen wird es allerdings einem geisteswissenschaftlichen Werk nur teilweise gerecht. Es gibt weder ein Vorwort, noch eine Einleitung oder eine Schlussbetrachtung. Denn auch bei einer Biographie wären einleitende Worte mit einer Forschungsfrage und einer These sowie ein umfangreiches kritisches Resümee über PAYERs Leistungen wünschenswert. Zudem fehlt eine kritische Auseinandersetzung mit der bereits über PAYER verfassten Literatur. Auch die Zitierweise ist in wissenschaftlicher Hinsicht mangelhaft. Während die direkten Zitate alle richtig zitiert wurden, fehlen bei einem großen Teil der sinngemäß wiedergegebenen Daten die Belege. Das Literaturverzeichnis ist für ein Buch von etwas mehr als 250 Seiten etwas dürftig. Die bereits vorhandene wissenschaftliche Literatur zur Österreichisch-Ungarischen Nordpolexpedition wurde nur teilweise berücksichtigt. Eine Kontextualisierung von PAYERs wissenschaftlichen Leistungen hat ebenfalls nicht stattgefunden.

Petra SvateK (Wien)

Brogiato Heinz Peter, Schelhaas Bruno (2014), „Die Feder versagt...“ Feldpostbriefe aus dem Ersten Weltkrieg an den Leipziger Geographie-Professor Joseph Partsch. Leipzig, Leipziger Universitätsverlag. 422 S., 69 Abb. ISBN 978-3-86583-871-1.

Das Buch stellt eine Edition von Kriegsbriefen aus dem Ersten Weltkrieg dar und wurde zum Gedenkjahr 2014 publiziert. Dabei bearbeiteten die Herausgeber Heinz Peter BRogiaTo und Bruno 
SCHELHAAS vom Leibniz-Institut für Länderkunde mehr als 300 Briefe und Postkarten, die sich heute im Nachlass des bedeutenden deutschen Geographen Joseph PARTSCH (1851-1925) im „Archiv für Geographie“ befinden. Die meisten der edierten Briefe und Postkarten wurden von Geographen im Feld an PARTSCH verfasst und geben einen wichtigen Einblick in ihre Arbeit und ihren Alltag. Diese Geographen waren vor allem Schüler von Partsch (Kurt Eismann, Lothar Franke, Fritz Heimann, Alfred Jentzsch, Kurt Krause, Hans Rudolphi, Martin Treblin, Harry Waldbaur, Hubert Winkler u.a.). Aber auch Briefe von Kollegen (Albrecht Penck, Franz Kossmat) und ehemaligen Assistenten (Otto Lehmann, Alfred Merz, Erwin Scheu) konnten ausgewertet werden. Joseph PARTsCH war zur damaligen Zeit Universitätsprofessor für Geographie an der Universität Leipzig.

Die Herausgeber wollten mit dem Buch ,einen Baustein zur Quellengattung ,Feldpost‘ beisteuern, darüber hinaus einen wissenschaftshistorischen Beitrag zum Thema ,Geographie und Krieg“ leisten“ (S. 7). Dieses Ziel haben sie ohne Zweifel erreicht. Die Geschichte der Geographie im Ersten Weltkrieg ist zudem bis heute kaum erforscht worden, wodurch dieser Band einen wichtigen Beitrag zu diesem Forschungsdesiderat leistet. Die Ausführungen von Brogiato und SchelHAAS beginnen mit einer Einleitung, in der sie eine umfassende Einführung in ihre Arbeitsmethodik, die Archivalien und Zielsetzungen geben (S. 7-11). Zudem beinhaltet die Einleitung auch eine Biographie über PARTSCH, Informationen zu den Absendern der Feldpost und eine kritische Auseinandersetzung mit den Inhalten der Feldpost (S. 12-27). Nach der Einleitung folgen in alphabetischer Reihenfolge die einzelnen Korrespondenzpartner mit kurzen biographischen Angaben und ihren wortwörtlich wiedergegebenen Briefen und Postkarten (S. 29-383). Von den meisten Personen lagen bis zur Publikation dieses Buches noch keine Biographien vor, was den Wert des Buches ohne Zweifel noch steigert. Die Biographien konnten von BROGiaTo und SCHELHAAs vor allem durch das Studium der Studentenkartei der Quästurbehörde im Leipziger Universitätsarchiv und der Dissertationen eruiert werden. 403 Anmerkungen komplettieren schließlich dieses Editionswerk (S. 385-397).

Den Abschluss des Buches bilden zwei Fachartikel von Nicolas GinsBurger (S. 399-414) und Heinz Peter BRogiato. Der französische Geographiehistoriker GinsBURGer berichtet über „Feldpostbriefe als Quelle für die Geschichte der Geographie“ und schreibt zu Recht, dass sie nicht nur „,authentische Einblicke in das Kriegsleben“ geben, sondern auch „das Fortbestehen der scientific community, persönlicher und beruflicher Netzwerke trotz der täglichen Gefahren an der Front" (S. 411) zeigen. BRogiato beschließt den Band mit seinen Ausführungen zu „Geographielehrer in der Zeit des Ersten Weltkrieges“ (S. 415-420).

Das Buch von Brogiato und SchelhaAs besticht durch eine fundierte Quellenrecherche und ist für alle Forscher, die sich mit der Geschichte der Geographie während des Ersten Weltkrieges auseinandersetzen, eine ausgesprochen lohnenswerte Lektüre und eine wichtige Grundlage für ihre eigenen Forschungen.

Petra SvateK (Wien)

Dittmann Andreas (Hrsg.) (2014), National Atlas of Afghanistan. Bonn - Manama - New York - Florianópolis, Scientia Bonnensis. 124 S. ISBN 978-3-940766-73-1.

Der 2014 erschienene National Atlas of Afghanistan wurde vom Deutschen Akademischen Austauschdienst (DAAD) finanziert und ist ein Gemeinschaftsprojekt des Instituts für Geographie der Universitäten Gießen (Prof. Dr. A. Dittmann), des Department of Geography der Universität Kabul (Prof. Dr. Sardar M. KoHISTANI) sowie des Afghan Geodesy and Cartography Head Office (Eng. A. Rauf YARI), das auf jahrelanger Kooperation zwischen den Partnern und deren Teams basiert. 
Eine wesentliche Herausforderung des Projekts war der Zugang zu verlässlichen aktuellen und qualitativ gehaltvollen statistischen Daten. Durch die Triangulation verschiedener interner und externer Datenquellen ist es gelungen, ein höchst respektables Werk zu generieren, das neben einem Überblick über physisch-geographische Gegebenheiten (z.B. Geologie, Tektonik, Klima, Hydrographie, natürliche Ressourcen) auch fundierte thematische Karten mit humangeographischen Inhalten und Spezialthemen (z.B. Wirtschaft, Bevölkerung, Bildungs- und Gesundheitswesen, Entwicklung politisch-administrativer Grenzen) in ihrer räumlichen Verteilung enthält. Ein inhaltlicher Schwerpunkt der Darstellung des sich im Wiederaufbauprozess befindlichen Afghanistans liegt auf der Entwicklung des Humankapitals, insbesondere der Entwicklung des Bildungs-, Gesundheits- und Hochschulwesens.

Die ausgewählten Themen werden auf jeweils einer Doppelseite (Querformat) dargestellt und beinhalten neben einer thematischen Karte ergänzende Fotos sowie einen Textteil, der eine Übersicht zum jeweiligen Thema bietet. Der Atlas ist als direkter Nachfolger des ersten Nationalatlasses (1984) von höchster Relevanz als aktuelle Informationsquelle für Interessierte aus Wissenschaft und Wirtschaft.

Nadine SCHARFENORT (Mainz)

Fischer Karl (2015), Wien 1609. Ansicht aus der Vogelperspektive von Jacob Hoefnagel. Schleinbach, Edition Winkler-Hermaden. 15 S., 3 Bildtafeln mit einer Abbildung. ISBN 978-39503739-4-3.

Jacob Hoefnagel (1573-1633), seit dem Jahre 1602 Kammermaler Kaiser Rudolf II., entstammte einer Amsterdamer Künstler- und Graphikerfamilie. 1609 schuf er im Auftrag des Kaisers seine berühmte Vogelschaudarstellung Wiens, welche die Stadt von Norden aus zeigt und wegen ihrer hervorragenden Qualität viele Jahrzehnte hindurch immer wieder reproduziert wurde. Im Jahr 2015 wurde diese Ansicht von Karl FISCHER neu herausgegeben und ausführlich kommentiert. Der 16 Seiten umfassende Text gibt zunächst einen umfangreichen Überblick über das Leben von Jacob Hoefnagel von seiner Geburt am 25. Dezember 1573 über seine diplomatische Tätigkeit bis hin zu seinem Tod am 2. Oktober 1632. Der Hauptteil ist schließlich der Vogelschauansicht gewidmet. Neben einer genauen Beschreibung beleuchtet FISCHER auch ihre Entstehungsgeschichte und das Aussehen der Stadt Wien vor dem Dreißigjährigen Krieg. Daher ist dieses Werk nicht nur für Kartographie- und Geographiehistoriker von Bedeutung, sondern auch für all jene, die sich mit der baulichen Entwicklung der Stadt Wien auseinandersetzen.

Petra SvateK (Wien)

Freytag Tim, Gebhardt Hans, Gerhard Ulrike, Wastl-Walter Doris (Hrsg.) (2016), Humangeographie kompakt. Berlin - Heidelberg, Springer Spektrum. XIII + 188 S., zahlr. Tab. und z.T. farbige Abb. ISBN 978-3-662-44836-6 (eBook: ISBN 978-3-662-44837-3).

Das Buch wurde ähnlich wie „Physische Geographie kompakt“ (2010) als Ergänzung zum umfassenden Werk „Geographie. Physische Geographie und Humangeographie“ (Spektrum, 2. Aufl. 2011, Neudruck 2016) konzipiert und hat das Ziel, ,einen Überblick über die wichtigsten Themen der zentralen Teilgebiete der Humangeographie zu geben und dabei die emerging fields in Forschung und Lehre in den Vordergrund zu stellen“. Zielgruppen sind „Studieninteressierte und Studierende in den Bachelor- und Lehramtsstudiengängen der Geographie“. Der Band enthält acht Kapitel, wobei das erste von den vier Herausgebern gemeinsam, die übrigen zumeist von je zwei anderen Autoren verfasst sind: 
Kapitel 1 „Humangeographie heute: eine Einführung“ (12 Seiten) listet als aktuelle Fragen des Faches genau jene auf, die in den Kapiteln 2 bis 8 aufgegriffen werden. Danach werden die groBen Entwicklungslinien der Humangeographie (von Geodeterminismus bis Poststrukturalismus) skizziert.

Kapitel 2 „Gesellschaft und Umwelt“ (A. MatTisseK, P. SAKDAPOLRAK, 25 S.) identifiziert, ausgehend von sozialwissenschaftlichen Aussagen, vier neue theoretische Ansätze zur Konzeptualisierung der Mensch-Umwelt-Beziehungen: Politische Ökologie, verfügungsrechtliche Ansätze, Ansatz der sozialen Verwundbarkeit, Resilienz - Kollaps - Restrukturierung. Anschließend werden sechs aktuelle Fragestellungen näher erläutert.

Kapitel 3 „Bevölkerung und Migration“ (R. WeHrhahn, 28 S.) ist zweigeteilt. Teil 1 behandelt Grundbegriffe und Konzepte der Bevölkerungsgeographie und der geographischen Migrationsforschung sowie den demographischen Wandel. Teil 2 erläutert Grundbegriffe und Prozesse der Migration und als ,neue“ Themen Translokalität und Multilokalität. Abschließend wird Bevölkerungs- und Migrationspolitik thematisiert.

Kapitel 4 „Mensch und Gesellschaft“ (T. FreYtAG, S. Mössner, 22 S.) bietet nach kritischer Diskussion einiger sozialwissenschaftlicher Grundbegriffe einen kurzen Überblick über die Disziplingeschichte der Sozialgeographie und spezifiziert neuere Beiträge zu ihrer theoretischen Fundierung. Danach werden Phänomene sozialer Differenzierung am Beispiel von fünf Dimensionen vorgestellt.

Kapitel 5 „Kultur und Politik“ (B. Korf, D. WASTL-WALTer, 26 S.) versucht unter Bezugnahme auf den cultural turn eine gemeinsame Darstellung von Kulturgeographie und Politischer Geographie. Als Kulturphänomene werden Sprache, Geschlecht, Religion und Nation sowie die Globalisierung thematisiert. Der Abschnitt „Politische Geographie“ beginnt mit der Frage nach dem Wesen des „Politischen“ und geht u.a. auf Kritische Geopolitik und Geographische Konfliktforschung ein.

Kapitel 6 ,Stadt und Urbanität“ (L. BASTEN, U. Gerhard, 25 S.) behandelt historische Phasen der Stadtentwicklung (inkl. Sub- und Reurbanisierung), soziale Räume und Fragmentierungen (Segregation, Gentrifizierung, Privatisierung), Umstrukturierungen, Wandlungen und Vernetzungen (u.a. Neoliberalisierung, Metropolitanisierung und Entwicklung von Global Cities, Postmodernisierung).

Kapitel 7 „Wirtschaft und Entwicklung“ (H.-M. ZADEMACH, Сн. Schulz, 22 S.) erläutert, nach einem einleitenden Exkurs über die hidden champions der deutschen Wirtschaft, u.a. die Konzepte Global Value Chains und globale Produktionsnetzwerke. Als neuere Erklärungsansätze der regionalen Wirtschaftsentwicklung werden Pfadabhängigkeit, evolutionäre Perspektive und Social Studies of Technology vorgestellt.

Kapitel 8 „Nach der Entwicklungsgeographie“ (B. Korf, E. Rothғuss, 21 S.) geht von der Frage aus, warum die Entwicklungshilfe nicht zur Überwindung der Armut im globalen Süden beigetragen hat und analysiert die Paradigmen der bisherigen Entwicklungsforschung und Entwicklungspraxis. Abschließend wird eine neue Entwicklungsgeographie als „kritische geographische Sozialforschung im globalen Süden“ postuliert.

Das größte Verdienst dieses Buches ist die zusammenschauende Charakteristik der neuen Strömungen (die zumeist durch Nachbarwissenschaften angeregt wurden) in der Humangeographie. Die aufgelistete Literatur ist hochaktuell, fast die Hälfte der Titel ist erst nach 2010 (Redaktionsschluss des Großbands) erschienen. Der Band ist reich illustriert, die Abbildungen sind überwiegend instruktiv (Ausnahmen: S. 32 Bildtext fehlerhaft? S. 167 Foto rechts oben unverständlich). Die didaktische Aufbereitung ist gut, am Ende jedes Kapitels findet man „Zentrale Begriffe und Konzepte“ (je etwa 20), „Literaturempfehlungen“ (jeweils 4-6 Titel) und eine längere Literaturliste (je ca. 50-90 Titel, etwa zur Hälfte englischsprachig). Das Stichwortverzeichnis nennt neben Sachobjekten auch die behandelten theoretisch-konzeptionellen Ansätze, dazu eine Auswahl älterer 
Autoren aus Geographie, Soziologie und Philosophie (und P. SLOTERDIJK als einzigen lebenden Autor); darüber hinaus werden im Text zahlreiche aktuelle Autoren zitiert.

Es fällt auf, dass in der Betitelung der meisten Kapitel das Wort Geographie bewusst vermieden wird. Dies wird mit dem disziplinübergreifenden Charakter der Fragestellungen begründet; dadurch „soll eine integrative humangeographische Sichtweise betont werden“. Diese Begründung hat etwas für sich, aber es erscheint fraglich, ob damit Studieninteressierte für das Fach Geographie gewonnen werden können.

In allen Kapiteln wird mehr oder weniger explizit ein relativistisch-konstruktivistisches Weltbild vermittelt. Dies mag einen nicht geringen Teil der Zielgruppen ansprechen, ist aber eine Form des methodologischen Monismus und eine Einengung der Argumentation. So wird etwa die Frage der Abgrenzung von Natur und Kultur, die sowohl in Kapitel 2 als auch in Kapitel 5 behandelt wird, als unbeantwortbar offengelassen. Die meisten Kapitel hinterlassen - zum Beispiel das Resümee des rein diskursanalytischen Kapitels 8 - zwar den Eindruck großer Vielfalt, aber auch einer gewissen Beliebigkeit und Machtlosigkeit der Wissenschaft.

Die Zukunftsperspektiven am Ende der meisten Kapitel betreffen überwiegend Entwicklungen im innerwissenschaftlichen Bereich. Der Beitrag der Humangeographie zur Lösung der drängenden Probleme der heutigen Menschheit hätte deutlicher herausgestellt werden können.

Albert HOFMAYER (Wien)

Freytag Tim, Jahnke Holger, Kramer Caroline (2015), Bildungsgeographie (= Geowissen kompakt). Darmstadt, Wissenschaftliche Buchgesellschaft. 135 S., zahlr. Tab. und Abb. ISBN 9783-534-24983-1.

Wie bei jedem Lehrbuch mussten die Autoren und die Autorin dieses Bandes einen wohlüberlegten Ausgleich zwischen der notwendigen Kompaktheit und Verdichtung des Stoffes, einer eingängigen didaktischen Aufbereitung komplexer Zusammenhänge und einer überzeugenden Positionierung des behandelten Themas im interdisziplinären Gesamtgefüge finden. Dies ist ihnen aus der Sicht des Rezensenten hervorragend gelungen. Die Bildungsgeographie ist ein eher junges Forschungsfeld unseres Faches, das von Autoren wie Robert GeIPel und Peter Meusburger (Heidelberg) maßgeblich entwickelt und geprägt wurde. Die drei Autoren des Lehrbuches sind in der Heidelberger Schule der Bildungsgeographie verankert und haben sich bereits in ihren Dissertationen mit bildungsgeographischen Themen befasst. Das Buch wendet sich nicht nur an Studenten, sondern auch ,an einen disziplinübergreifenden Kreis von Wissenschaftlerinnen und Wissenschaftlern, die an einer raumbezogenen Bildungsforschung interessiert sind" (S. VII).

In den ersten beiden Abschnitten wird deshalb das Thema „Bildung“ in knapper Form als disziplinübergreifender Forschungsgegenstand dargestellt. Kapitel drei stellt die Entwicklungslinien der Bildungsgeographie dar, wobei der deutsche Sprachraum im Vordergrund steht. Im eigentlichen Hauptkapitel vier werden dann „Leitthemen der Bildungsgeographie“ erörtert. Hier soll - ohne Anspruch auf Vollständigkeit - das Spektrum der Themen aufgezeigt werden, die in der geographischen Bildungsforschung von Interesse sind. Der Stoff wird hier nach sechs Teilkapiteln gegliedert: Bildungseinrichtungen und ihre Standorte, regionale Disparitäten der Bildungsbeteiligung und des Bildungserfolgs, Bildung und politische Räume, Bildungsentwicklung in globaler Perspektive, Bildung und Migration sowie Bildung und Wirtschaft. Jedes Teilkapitel beginnt mit einer Besprechung der konzeptionellen Grundstruktur. Anschließend werden jeweils drei spezifische bildungsgeographische Blickwinkel auf die jeweiligen Themenbereiche vorgestellt. Das - vielleicht allzu knappe - Schlusskapitel fünf ist Perspektiven der Bildungsgeographie gewidmet. 
Der Text besticht durch klare und eingängige Formulierungen sowie eine sehr überzeugende Gliederung. Eine Schnell-Lese-Straße (Marginalien) erleichtert die Orientierung und die rasche Erfassung der wichtigsten Aussagen; Exkurskästen werden für kompakte Definitionen oder inhaltliche Kurzdarstellungen außerhalb des Fließtextes genutzt. Der Text wird durch zahlreiche Tabellen, Karten und überaus anschauliche Graphiken ergänzt. Kurz zusammengefasst: ein Lehrbuch, wie man es sich wünscht.

Peter WeIchHART (Wien)

The $17^{\text {th }}$ volume of the German-language series "Geowissen Kompakt" is a remarkable contribution to multidisciplinary academic debates in geographies of education, schooling and children. As its authors underline, it has the twofold aim of presenting new topics, approaches, methods and research results that have emerged since Peter Meusburgen's 1998 seminal work "Bildungsgeographie" about geographies of education and knowledge, while providing insight into the field of study in a way easily understandable even for university students. Such attempts always face a double challenge. On the one hand, they can easily result in a book that merely supplements the pioneering work, where the message of the former is hard to understand for those not familiar with the latter. On the other hand, the willingness to present a volume that is meaningful on its own might lead to a number of repetitions and little new information compared to the former work. The three authors of the current book, however, managed to maintain high standards while also finding a balance between both extremes and providing a very open-minded and state-of-the-art overview of the subject, which is easy to follow and comprehend even for those having limited background knowledge on the issue.

The authors begin by discussing some conceptual questions on how education and schooling can be analysed in scientific research. Here they also present the development of this field of study in the domain of geography. Then, they scrutinise education and schooling along locational, social, political and economic lines, dealing with all levels of education and its formal and informal manifestations as well. Given its clear and well thought-out structure, the chapters can be well used as readings for a university seminar.

There is a lot of merit in the book, some of which I find especially important. The authors convincingly present the social constructedness and, thus, historical and geographical embeddedness and contextuality of such seemingly simple categories like "education". They present the utmost importance of the political dimension, moving away from traditional positivistic narratives that naturalise partial interests and power asymmetries around education as 'given', while consciously keeping distance from art-for-art-sake criticism and empty buzzwords. Discussions about the growing commodification of education, the link between education and international migration, or ongoing colonial heritage in schooling in many regions of the Global South raise highly relevant questions and provide useful and inspiring findings for economic and political geographers as well. Also valuable are sections highlighting how attempts aimed at improving social justice in education and schooling might hinder the same goal in another sense. For example, the authors discuss how the free choice of school, while providing more space for the rights of individuals, tends to result in increasing competition between institutions and, hence, social segregation and school closures, which is an especially risky trend in localities where the school serves as a central institution in local community life. Great attention is paid to the issue of scale. Global, national, regional and local dimensions are all considered and the strong links between all of them are clearly presented. Meanwhile, the authors scrutinise issues in an historical perspective, which sheds new light on many contemporary challenges, such as obstacles for a more international governance of education due to structures inherited from the era of nationbuilding. 
A definite strength of the book is that it contributes from the perspective of geographies of education and schooling to general conceptual debates that are highly relevant but are still surrounded by contested concepts without a broad scientific consensus. An example of this are references to the diverse and sometimes conflicting notions of planning (e.g. Chapter 4.1.4). From a post-Communist East Central European point of view, it might be interesting to substitute the commonly used binary categories of "market principle" versus "planned economy" (referring to former Communist countries) by a narrative concentrating on property regimes and the scale. In fact, rigorous economic planning in the service of market actors and along market principles is not impossible, as examples like Singapore, Japan or South Korea show. Furthermore, it is not alien to full-fledged market economies such as the United States, either, where the scale is different, since planning is mainly done by enterprises instead of the federal state. Thus, putting the question of which property relations dominate the system where planning is done, and which is the dominant scale of planning could help conceptualise and scrutinise related issues less constrained by epistemologies inherited from the $20^{\text {th }}$ century and specifically the Cold War period, and more adapted to shifting social and economic realities after the millennium.

The book employs a great variety of examples from both German-speaking countries and other geographical contexts, and mobilises state-of-the-art scientific results from various disciplines, mainly from German-speaking researchers, but with an outlook to several key Anglophone texts as well. Consequently, it enables a sophisticated understanding of related trends especially in Germany, but in their international context. These features make the volume a very valuable work for a German-speaking readership as well as those from other countries who are interested in actual trends of education in Germany-related data sources, and local academic concepts and results. Selected parts of the book, if translated into English and contextualised for foreign readers (perhaps in the form of international comparisons), could serve in the future as basis for further valuable publications reaching a wide international public including those without a proficiency in German. In light of the virtues of the book, such publications would be more than welcome.

Ferenc GYURIS (Budapest) ${ }^{1)}$

Haferburg Christoph, Huchzermeyer Marie (Hrsg.) (2014), Urban Governance in Post-apartheid Cities. Modes of Engagement in South Africa's Metropoples (= Urbanization of the Earth, 12). Stuttgart, Borntraeger Science Publishers. 337 S., 17 Tab. und 36 z.T. farbige Abb. ISBN 978-3-443-37015-2.

Dieser Band 12 aus der Reihe „Urbanization of the Earth“ ist zweifellos der zurzeit wichtigste Beitrag zur urbanen Entwicklung Südafrikas nach der politischen Wende 1994. Der Terminus governance ist als Gegensatz zu government zu verstehen und ist auf Deutsch nur zu umschreiben mit Regierbarkeit, Herrschaft oder Kontrolle. Gemeint sind damit die Aktivitäten unterschiedlichster Akteure außerhalb offizieller Regierungspolitik, ihrer planerischen und budgetären Entscheidungen oder Prioritäten. A. BenZ \& N. Dose (2010) bezeichnen governance als Regieren in komplexen Regelsystemen, K. SELLE (2012) definiert Stadtentwicklung aus der ,Governance-Perspektive' als veränderte Sicht auf den Beitrag öffentlicher Akteure zur räumlichen Entwicklung.

1) The review has been supported by the National Research, Development and Innovation Office - NKFIH under grant PD 121127. 
Mit der (politischen) Schwächung der Nationalstaaten durch die Globalisierung gewinnen einerseits privatwirtschaftliche, neoliberale Tätigkeiten stärker als bisher Einflüsse auf die Stadtgestaltung, andererseits eröffnen sich ebenso größere Spielräume für vielfältige Aktivitäten der Zivilgesellschaft, die dann beide mit- oder gegeneinander auf die aktuellen Konflikte und Lösungsansätze in urbanen Räumen einwirken. Dieses Spannungsfeld bildet das Leitmotiv des Bandes (S. 6), wobei $\mathrm{zu}$ fragen ist, ob Prozesse der urbanen governance weltweit gleichartig ablaufen oder ob es eine spezifisch ,südafrikanische“ Entwicklung der post-Apartheid-Demokratisierung mit eigener Dynamik und inneren Widersprüchen gibt. Handelt es sich um postkoloniale Gemeinsamkeiten aller Schwellenländer, des globalen urbanen Südens, um eine neue Dimension städtischer Entwicklung oder (nur) um eine Variante der global gesteuerten neoliberalen Investitionspolitik? Es gibt darauf (noch) keine eindeutige Antwort. Aber 23 Autoren und Autorinnen zeigen in 17 Kapiteln ein weit gespanntes Spektrum an empirischen Befunden, sozio-politischen Überlegungen und planerischen Empfehlungen zur künftigen Steuerung.

Der Band behandelt die südafrikanischen Metropolen mit ihren Peripherien und gliedert sich in fünf Hauptteile. Der erste befasst sich mit dem theoretischen und empirischen Kontext des Bandes insgesamt und der Kapitel untereinander. Die drei nachfolgenden behandeln Akteure (key role players) - zunächst das government mit seinen vielfältigen Institutionen und Aktivitäten, gefolgt von Personen und Einrichtungen der breiteren Öffentlichkeit (der ordinary city dwellers), - und viertens die wachsende Einflussnahme des Privatsektors auf urbane Prozesse. Während diese Kapitel immer auch räumliche Aspekte miteinbeziehen, soll der fünfte Hauptteil dazu dienen „help us understand key role players in governance trough a focused spatial lens“ (S. 7). Der (kapitalschwache) Staat gerät bei diesen Prozessen zunehmend zwischen die Fronten einer rasch wachsenden Bevölkerung, die ihren ,gerechten Anteil' nach dem Sieg über das ApartheidsRegime und der erhofften ökonomischen Prosperität einfordert, und einer steigenden Marktmacht nationaler wie globaler Investoren. Etliche Kapitel legen ihren Fokus auf Fragen der (möglichen) Partizipation der Bewohner an der urbanen Entwicklung, die zugleich als Schlüsselrollen der Demokratisierung gesehen werden (z.B. Verbesserungen der Infrastruktur, Housing, Neubewertung des öffentlichen und privaten Raums, gated communities). Die vielfach ungelösten Probleme bewirken zunehmend, insbesondere in den ausgedehnten Armenvierteln, wütende Proteste bis hin zu Massenunruhen.

Das Erbe der Apartheid ist nicht bewältigt, sondern wirkt noch immer als determinierender Faktor, gerade auch in sozialen und politischen Auseinandersetzungen. Ist die anhaltende räumliche ethnische Segregation nur noch eine Übergangsphase oder für weitere Generationen bestimmend? Die Autoren nähern sich diesem sensiblen Kernthema recht vorsichtig. Werden im jüngsten Zensus (2011) noch Rassen ausgewiesen, so sprechen die Autoren überwiegend von ,population groups“ oder ,ethno-nationality“. Inwieweit werden dadurch Klassen- und Statusunterschiede erklärt oder verwischt?

Dieser umfangreiche Band analysiert die rezente Entwicklung südafrikanischer Metropolen differenziert und engagiert. Der urbane Raum ist ein hochpolitischer Raum, in welchem eine Vielzahl von Individuen wie Gruppen um ihre Einbeziehung in die städtische Gesellschaft kämpfen, während andere genau dies zu verhindern suchen. Die hier analysierten grundsätzlichen wie alltäglichen städtischen Auseinandersetzungen und Allianzen spiegeln aber auch die Problemlagen der Gesamtgesellschaft. Somit lässt sich dieser Sammelband in dreifacher Hinsicht mit Gewinn lesen: Er liefert die mit Abstand umfangreichste Interpretation der aktuellen Stadtentwicklung und ihrer Akteure in Südafrika, damit auch einen wertvollen Beitrag zur internationalen Stadtforschung, und nicht zuletzt für Kernfragen der Politischen Geographie wie Macht und Raum oder Territorialität politischer Konflikte.

Heinz NisSEL (Wien) 
Jordan Peter, Woodman Paul (Hrsg.) (2016), Place-Name Changes. Proceedings of the Symposion in Rome, 17-18 November 2014 (= Name \& Place, 5). Hamburg, Verlag Dr. Kovač. 492 S., zahlr. Tab. und Abb. ISBN 978-3-8300-8423-5

Peter JoRdan and Paul Woodman, well-known toponomasticians and active members of the United Nations Group of Experts on Geographical Names (UNGEGN) have put together an excellent collection of texts written by respected researchers from Europe, Asia, Africa and South America. The unifying theme for all the texts is - as the title of the book hints - place-name changes. This is, by all means, a complex topic since linguistic idiosyncracies, place-naming traditions, toponymic conflicts, legal frameworks, commercial interests, ethnic composition, and historical and political events influence deeply toponymic transformations and produce a great diversity of toponymic developments difficult to fit into a simple comparative and analytical framework. The individual chapters document this diversity across time and space and show the importance of place names for the formation of individual and collective identity, the interpretation of cultural landscapes, and the legitimisation of political regimes and territorial demands.

The book is divided into five sections. The first contains four texts, which attempt to address the theoretical, conceptual, terminological, and methodological challenges raised by the aforementioned toponymic diversity. For example, Paul Woodman problematises the concept of „change“ and how our understanding of this concept affects the study of place-name changes. Enzo CAFARELLI, on the other hand, points out that place names not only change from one name to another (as in renaming a street) but in numerous instances they also change their onymic category (e.g. from a place name to a personal name or a chrematonym and vice versa).

The second section consists of twelve texts dedicated to country and regional case studies of place-name changes. Peter E. RAPER, for example, offers a complex insight into the complicated linguistic and toponymic situation of South Africa and the influence of the Bushmen languages on current place names. Paolo DE MENEzes with colleagues analyse the toponymic transformation of Brazil as documented on historical maps and Cosimo PALAGIANO offers an overview of the evolution of the Italian toponymic landscape.

The third section focuses on place-name changes in the urban space. It contains eleven texts dealing with the politics of street naming in different cities across the world. Wengchuan HuANG, for example, provides a critical reflection of the politics of street naming in Shanghai, China, Matjaž GERŠIČ and Drago KLADNIK describe the transformation of urban toponymy in Lujbljana, Slovenia, and Adyanis Collazo Allen gives an insider's perspective on the contemporary toponymic practices in Havana [La Habana], Cuba.

The fourth section contains three texts, which address toponymic conflicts and changes in multicultural situations. To mention a few, Partik TÁtrai and Agnes ERóss analyse the toponymic silence in contested spaces in Cyprus and Central and Eastern Europe and Ivana CRLJENKo and Ivan ZuPANC provide a critical look on place-name changes and conflicts in Croatian Istria [Istra].

Finally, the last section consisting of four texts deals with the impact of specific historical events on place names. Again, to mention at least a few, Brahim АтоU, for example, interprets the echos of colonialism in the toponymic landscape of Algeria and Peter JoRDAN offers a study of the ambivalent interpretation of Tito"s heritage in the toponymic landscape of the successor states of Yugoslavia.

It is never easy to edit a book and it is even more difficult when editing a volume containing over thirty chapters written by different authors on related but not entirely identical topics. Yet, in spite of this difficulty, Peter JORDAN and Paul WOODMAN have succeeded in publishing an important and balanced book, which will serve well to anyone interested in place-name changes, both in theory as 
well as, and perhaps more importantly, in the multiplicity of their everyday occurrences in different parts of the world.

Přemysl MÁcha (Ostrau [Ostrava])

KERSTEN Jens (Hrsg.) (2016), Inwastement. Abfall in Umwelt und Gesellschaft (= Kulturen der Gesellschaft, 26). Bielefeld, transcript Verlag. 338 S., 2 Tab. und 12 Abb. ISBN 978-3-8376-3050-3.

Das Abfallthema ist man gewohnt nach Verursachern und Beseitigungskosten, nach gesundheitlicher Schädigung und Vermeidungsstrategien aufzugreifen, usw. Das geht im vorliegenden Buch auch, wenn man im Sachregister sucht - oder im Orts- und Landesregister zwischen Ägypten und Zwickau. In beiden Fällen ist es interessant, überraschend und erhellend, zu welchen Textteilen man derart gelangt. Denn überaus erfrischend ist die Gliederung des facettenreichen Generalthemas ebenso wie es die zwölf Themen sind, die die Forschungsschwerpunkte der 16 Autorinnen und Autoren widerspiegeln. Diese Themen werden den folgenden lebensweltlichen Kategorien zugeordnet: Dinge und Orte, Wege und Zeiten.

Jens KERSTEN weist in einer Einführung auf den Zusammenhang von Abfall mit Gebrauchspraxis und Normen hin und auf die Probleme des Interdisziplinären in einer Thematik, die in der Regel naturwissenschaftlich präzise festgemacht und gesellschaftswissenschaftlich/politisch verhandelt wird. Unter den Beiträgen fällt jener über „Phosphorwege in Richtung Nachhaltigkeit“ insofern aus dem Rahmen, als er der einzige ist, der das Geschriebene durch Graphiken unterstützt. Er stammt von Frau Prof. BINDER, Ludwig-Maximilians-Universität München, deren Lehrkanzel so benannt ist wie das Generalthema der Geographie (Mensch-Umwelt-Bezüge). Die anderen Beiträge kommen mit Worten allein aus, auch, weil den sehr informativen und äußerst heterogenen Texten auch die Funktion zukommt, das Wesentliche eines Themenbereiches zu präsentieren, wie das einem Reader eben angemessen ist. Das erfordert, einige der angesprochenen Bereiche schlagwortartig zu nennen - so „Hausmüll und Industriemüll““, „Lebensmittelabfälle als ethisch-kulturelle Herausforderung“, „, $\mathrm{CO}_{2}$-Emissionen und Gerechtigkeit“; oder mit Langzeitaspekten: „Globale Stoffströme seit dem Archaikum“, „Bioarchäologie des Abfalls“, „Juristische Metaphysik - atomare Endlagerung“. Am Ende wird klar, dass unter „Abfall und Gesellschaft“ auch Kriminelles zu verstehen ist. Man liest neugierig und mit Gewinn - was für jeden der Texte in diesem Buch gilt. Eigenartig zuweilen ist die Vermengung von naturwissenschaftlichen Fachbegriffen mit dem sozialwissenschaftlichen Grundtenor dieses Buches.

Martin SEGER (Klagenfurt a.W.)

KuTtLER Wilhelm (2013), Klimatologie. 2., aktualisierte und ergänzte Auflage. Paderborn, Verlag Ferdinand Schöningh. 306 S., zahlr. Tab. und z.T. farbige Abb. ISBN 978-3-8252-4059-2.

Neuauflagen und Neuerscheinungen von Lehrbüchern sind dem wissenschaftlichen Erkenntnisfortschritt geschuldet, welcher sich bei dem in Rede stehenden Werk in der im Vorwort genannten Erweiterung durch einige Bereiche manifestiert. Es sind die Darstellungen des Einflusses des Mondes, der Solarenergie, der Windkraft, der turbulenten Wärmeflüsse, der bioklimatischen Indizes und der lokalen Maßnahmen gegen den globalen Klimawandel.

Zielgruppe dieses Lehrbuchs sind „Studierende der geowissenschaftlichen Fächer und andere interessierte Personen.“

Die Kapitelgliederung weicht deutlich von den traditionellen Gliederungen ab und ist eine dynamisch aufbauende Hinführung von den Grundlagen und Begriffsbestimmungen bis hin zu den 
aktuellen Fragen der gesellschaftsrelevanten oder anthropogenen Wirkungen und Rückwirkungen. Im Einzelnen werden abschnittsweise behandelt: die Erde mit den astronomischen und geophysikalischen Grundlagen, Atmosphäre, Luftdruck und Temperatur, Strahlungs- und Wasserhaushalt, das Wasser und seine klimatische Wirkung, der Wind, die allgemeine Zirkulation der Atmosphäre, Klimatypen und Klimaklassifikationen, Bioklima und Geländeklima, Stadtklima, Treibhauseffekt und Ozonloch und schließlich die lokalen Maßnahmen gegen den globalen Klimawandel.

Die wesentlichen Eigenheiten der Darstellung sind schon im Sinne des Evres des Autors die auffallende Verschiebung der Gewichte der Inhalte von den ,klassischen“ Fragen der Klimatologie hin zu den umwelt- und gesellschaftsrelevanten Fragen der letzten vier Abschnitte, die auch - besonders im Falle des Stadtklimas und der Lufthygiene - dem unmittelbaren Forschungsfeld des Autors zuzurechnen sind. Diese Bereiche sind auch auf dem neuesten Forschungsstand, aktuell und vielfach auch originär. Dazu kommt eine starke physikalisch-mathematische Ausrichtung, die die Nachvollziehbarkeit der wichtigsten Wirkungen mittels physikalischer Gesetze und mathematischer Formeln gestattet, die aber gleichermaßen ausgeblendet werden können. Die ganze Darstellung ist im Sinne eines ökonomischen ,Text-Haushaltes‘ sehr komprimiert, aber trotzdem weitgehend vollständig und nachvollziehbar, erfordert aber eine konzentrierte Befassung, um wirklich vertiefte Einsichten zu erlangen.

Wie in allen Darstellungen sind aber auch gewisse Ausblendungen anzumerken und offene Wünsche anzumelden. So vermisst man - wie eigentlich in allen vergleichbaren Darstellungen - einen Abschnitt oder wenigstens eine kurze Erwähnung des Gebirgs- und Hochgebirgsklimas. Als kleinere Wünsche könnte man die gegenüber der genetischen Klassifikation von FLOHN widerspruchsfreie, weil auf Luftmassen aufbauende Klassifikation nach Alissow einfordern; eine bezüglich ihrer Faktoren stringentere Darstellung der Verdunstung; die Darstellung des Berg-Talwind-Systems und die diesbezüglich und auch bei den anderen Lokalwinden und thermischen Druckgebilden strengere Unterscheidung zwischen druckbedingten und dichtebedingten Winden bzw. thermischer Ausdehnung und vertikaler Bewegung unterschiedlich temperierter Luft. Auch die Zitierung der im Wetterdienst verwendeten Luftmassengliederung nach GEB wäre praxisnäher als jene von SCHREIBER.

Bei der formalen Präsentation sind die übersichtliche Gliederung, die Einleitungen für jedes Kapitel durch kurze Inhaltsübersichten, die Auflockerung durch Einschaltungen von ,Kästen “ mit vertiefenden Inhalten, ein Sachregister und ein farbiger Kartenteil oder farbige Wolkenfotos und nicht zuletzt ein Kasten mit den wichtigsten Abkürzungen und dem griechischen Alphabet besonders hervorzuheben.

Resümierend erhält die „KUTTLER-Klimatologie“ - schon wegen der unterschiedlichen Schwerpunkte - den Stellenwert einer unverzichtbaren Studien- und Weiterbildungsliteratur.

Herwig WAKONIGG (Graz)

MAGaš Damir (2013), Geografija Hrvatske [Geographie Kroatiens] (= Biblioteka Geographia Croatica, 46). Zadar, Sveučilište u Zadru - Odjel za geografiju, Izdavačka kuća Meridijani. 597 S., 17 Tab. und zahlreiche z.gr.T. farbige Abb. ISBN 978-953-331-040-4, 978-953-239-151-0.

MAGAš Damir (2015), The Geography of Croatia (= Biblioteka Geographia Croatica, 47). Zadar, University of Zadar - Department of Geography, Meridijani Publishing House. 597 S., 17 Tab. und zahlreiche z.gr.T. farbige Abb. ISBN 978-953-331-078-7, 978-953-239-191-6.

Kroatien grenzt zwar nicht an Österreich, ist aber ein ,gefühltes` Nachbarland und nicht nur durch die gemeinsame Geschichte, sondern auch durch die Rolle der österreichischen Außenpolitik 
beim Erlangen der Unabhängigkeit Kroatiens (1991), durch die kroatische Volksgruppe im Burgenland, die kroatische Arbeitsmigration nach Österreich und nicht zuletzt durch die Prominenz Kroatiens als altes (Abbazia [Opatija]!) und stets junges Reiseziel der Österreicher eng mit Österreich verbunden. Eine regionale Geographie Kroatiens, wie sie nun in Form eines umfangreichen, aber übersichtlichen, weil gut gegliederten, reich illustrierten und mit Karten versehenen Bandes, der auch in englischer Sprache erschienen ist, vorliegt, wird daher sicher auch in Österreich auf großes Interesse stoßen. Sein Autor Damir MAGAš ist an der jungen, erst 2003 gegründeten Universität Zadar tätig, war auch ihr Gründungsrektor und ist wohl der heute führende Geograph Kroatiens.

Diese regionale Geographie Kroatiens löst die aus sieben dünneren Bänden bestehende, in den Jahren 1974/75 erschienene Geographie der Sozialistischen Republik Kroatien (CRKVENČÍ et al. 1974/75) ab. Seither ist Kroatien ein unabhängiger Staat geworden und war Schauplatz eines Krieges, der in Bevölkerung und Wirtschaft tiefe Spuren hinterlassen hat. Es hat einen Transformationsprozess durchlebt, der sich auf alle Aspekte seiner Raumstrukturen auswirkte, und es hat sich in der internationalen Staatengemeinschaft, vor allem durch den Nato-Beitritt 2009 und die Mitgliedschaft in der Europäischen Union (EU) seit 2013 neu positioniert. Auch die geographische Forschung über Kroatien in den nun schon zahlreichen geographischen Universitätsstandorten Kroatiens und aus dem Ausland ist wesentlich vorangeschritten.

Der Autor beschreibt die Aufgabe dieses Buches sehr eindrücklich, wenn es im Vorwort der englischen Ausgabe heißt: , ,[...] in order for its culture and identity to survive, each nation needs to be aware of its emergence and development in time (the domain of history), and its language and culture (linguistics, history of art, etc.), but also the space it inhabits (both physical and social)." (MAGAš 2015, S. 6) Er bezeichnet dieses Werk auch als „first integrated, geographic monograph on independent Croatia, and a university textbook for the subject of Geography“ (ebendort).

Das in beiden Ausgaben 597 Seiten starke Buch ist in neun Hauptkapitel gegliedert. Das erste beschreibt auf 17 Seiten geographische Lage, Ausdehnung und Grenzen. Dabei werden sehr interessant auch die auf das heutige Kroatien im Lauf der Geschichte einwirkenden Kulturströmungen benannt: die mitteleuropäische, vor allem auch vertreten durch Katholizimus, Protestantismus und Judentum; die mediterran-italienische mit ebenfalls starken katholischen Elementen; die „balkanische“, zusammengesetzt aus dem osmanischen „Drang nach dem Westen“ und dem „serbischen Hegemoniestreben" mit islamischen bzw. byzantinischen Elementen.

Das lange (68 Seiten) Kapitel über die physisch-geographischen Grundlagen bietet über den üblichen thematischen Kanon hinaus u.a. eine Karte der Erdbeben von der Antike bis 2001, in der sich die südliche dalmatinische Küste als das Gebiet mit der größten Häufigkeit im heutigen Kroatien hervorhebt. Sehr ausführlich widmet sich das Kapitel dem Adriatischen Meer, u.a. der Wasserzirkulation, welche der kroatischen Adriaküste bis Istrien [Istra] frisches Wasser aus dem östlichen Mittelmeer zuführt und so für eine im Vergleich zur italienischen Küste bessere Wasserqualität sorgt.

Das 123 Seiten umfassende dritte Kapitel beginnt mit einer Regionalisierung des Landes nach physiognomischen Kriterien. Die so definierten Regionen werden sodann zumeist in zwei, manchmal aber auch in drei räumlichen Gliederungsstufen geographisch ganzheitlich, d.h. unter Berücksichtigung sowohl ihrer naturräumlichen als auch ihrer kulturräumlichen Merkmale beschrieben, wobei zahlreiche Fotos und Karten den Text vorzüglich ergänzen.

Das Kapitel 4 widmet sich auf 79 Seiten der historisch-geographischen Entwicklung, die durchaus auch die vorslawischen politischen Formationen zur Geltung kommen lässt, aber natürlich den kroatischen Staatsbildungen seit dem Frühmittelalter breiten Raum gibt. Die dazu gezeigte Kartenfolge würde auch einem Geschichtsatlas alle Ehre machen.

Das Kapitel über Bevölkerung und Siedlungen (51 Seiten) bezieht beim Merkmal „ethnische Zugehörigkeit“" auch die Kroaten in den Nachbarländern (darunter die Burgenland-Kroaten) und die 
seit dem späteren 19. Jh. intensive kroatische Auswanderung nach Übersee und ins übrige Europa mit ein, wobei nach dem Grundsatz „einmal Kroate - immer Kroate“ verfahren wird.

Das 70 Seiten umfassende Kapitel „Geographische Aspekte der kroatischen Wirtschaft“ kennzeichnet Kroatien als ein Land mit einer ,zentralen Peripherie“ (dem sich entvölkernden Gebirgsraum des Dinarischen Gebirges [Dinarsko gorje]) und zwei Wirtschaftsachsen - der des Save-Korridors mit der Agglomeration Zagreb und der des adriatischen Küstensaumes mit der zweit- und drittgrößten Stadt des Landes (Split bzw. Rijeka) und einem intensiven Tourismus.

Das im 7. Kapitel abgehandelte Thema der funktionalen Gliederung Kroatiens (101 Seiten) ist das ,Leibthema“ des Autors. Es wird entsprechend gründlich ausgeführt. Interessanterweise fließen hier aber Überlegungen zu einer Reform der Verwaltungsgliederung des Landes, die dem zentralörtlichen System nicht sehr adäquat ist und die den Autor ansonsten sehr beschäftigen, nicht mit ein.

Relativ dürr ist das Kapitel über „Kroatien und die internationale Gemeinschaft“ (5 Seiten), das sich mit einer Aufzählung der Mitgliedschaften Kroatiens bei internationalen Vereinigungen und Zusammenschlüssen von Nato und EU bis zur Arbeitsgemeinschaft Alpen-Adria und jener der Donauländer begnügt.

Das letzte Kapitel gibt schließlich auf 22 Seiten einen Überblick über die Entwicklung der kroatischen Geographie im Sinne einer Beschreibung der Aktivitäten und der Bedeutung von Geographen und geographischen Institutionen. Sie beginnt mit Herman Dalmatinac (ca. 1110-1143), Grgur von Zara (12. Jh.) und Marco Polo (1254-1323), konzentriert sich aber natürlich auf die Zeit nach dem Zweiten Weltkrieg.

Das Buch ist mit mehr als 1.000 farbigen Fotos und Karten in hervorragender Qualität reich illustriert, bietet Bibliographien nach jedem Kapitel und zusammengefasst noch einmal zum Schluss sowie ein Verzeichnis aller im Text vorkommenden geographischen Namen mit Seitenverweis. Es kann als die auf das Wesentliche reduzierte, in jeder Hinsicht gut aufbereitete und leicht zugängliche Summe geographischen Wissens über Kroatien bezeichnet werden und ist das Meisterstück des auch sonst bestens ausgewiesenen Autors.

\section{Zitierte Literatur:}

Crkvenčić I., Friganović M., Sić M., Pavić R., Rogić V. (1974/75), Geografija SR Hrvatske [Geographie der Sozialistischen Republik Kroatien], Bände I-VII. Zagreb, Školska knijga.

Peter JORDAN (Wien)

Opp Christian, Chifflard Peter (Hrsg.) (2014), Wasserforschung - Grundlagen und Anwendungen. Überregionale Beiträge aus Wissenschaft und Praxis (= Marburger Geographische Schriften, 147). Marburg/Lahn, Selbstverlag der Marburger Geographischen Gesellschaft. 259 S., zahlr. Tab. und z. T. farbige Abb. ISBN 978-3-88353-072-7.

Der genannte Band umfasst insgesamt 12 Einzelaufsätze, die abgesehen vom Grundthema „Wasser" durch außergewöhnlich heterogene Inhalte gekennzeichnet sind, was wohl darauf zurückzuführen ist, dass die Autoren jeweils aus ihren unmittelbaren Forschungs- und Arbeitsfeldern berichten und vom Herausgeber kein engeres Thema vorgegeben war. Dabei können praktisch alle Beiträge als komprimierte Darstellungen oder Zusammenfassungen von umfangreicheren Forschungsberichten oder Projektbeschreibungen verstanden werden. Diese Heterogenität betrifft nicht nur die Inhalte, sondern auch die regionale Zuordnung, wobei sich vier Beiträge auf Hessen beziehen, zwei auf Bayern, je einer auf Südtirol, Sachsen/Thüringen, ganz Deutschland, China und Zentralasien. Ein Beitrag ist 
der Schuldidaktik zuzuordnen. Solcherart ist auch keine generelle Stellungnahme möglich; eine auf die Einzelbeiträge bezogene muss sich allerdings auf nur streiflichtartige Anmerkungen beschränken.

Die Beiträge behandeln folgende Themen (keine wörtliche Zitierung der Titel): (1) Bedeutung des Klimawandels für die Siedlungswasserwirtschaft und Trinkwasserhygiene in Deutschland und Mitteleuropa, (2) Hochwasservorhersage in Hessen, (3) Klimawandel und Abflussgeschehen in Kleineinzugsgebieten in Hessen, (4) ökologische Durchgängigkeit von Oberlauf-Fließgewässern, (5) Schwermetallkonzentrationen im Uferbereich und im Fluss Lahn, (6) Grundwasserdynamik an der bayrischen Donau, (7) Grundwasserdynamik und Bodenwasserhaushalt im Südtiroler Obstbau, (8) Modellierung des Wärme- und Stoffhaushaltes des Ammersees, (9) Abflussbildung im Einzugsgebiet des Dongting-Sees [Dòngtíng Hú] in China, (10) Wasserprobleme in Zentralasien, (11) Geschichte der Verkehrsbedeutung von Saale und Unstrut und (12) Vorschläge für das Verbessern der Beziehung von Kindern zu Fließgewässern bei der Arbeit mit Kindergruppen.

Fast alle Beiträge sind das Ergebnis originärer Forschungsarbeiten vor Ort mit entsprechender Darstellung von interessanten Ergebnissen, die durchaus neue Erkenntnisse liefern oder praxisund gesellschaftsrelevante Bedeutung haben. Eine besondere Hervorhebung irgendeines Beitrags scheint dabei müßig, allerdings fallen die Arbeit über die ökologische Durchgängigkeit von Oberlauf-Fließgewässern (Problem der Straßendurchlässe) durch ihren Fokus auf einen bisher so gut wie unbeachteten Aspekt und die Arbeit über die Wasserprobleme in Zentralasien (Tadschikistan, Usbekistan) durch eine besondere Fülle an neuen und interessanten Informationen mit starkem geographischem und gesellschaftsrelevantem Bezug über einen wenig bekannten Raum besonders auf.

Von dieser Struktur etwas abweichend, d.h. nicht die unmittelbare hydrologische Forschung vor Ort betreffend, sind die Beiträge Nummer 1 als kompilatorische Zitierung und Diskussion der generellen aktuellen Probleme des Klimawandels für die angewandte Hydrologie, fußend auf einer Fülle an benutzter Literatur, Nummer 11 als historische und mit historischen Methoden (Quellenstudium) arbeitende Darstellung und Nummer 12 als didaktische, aber durchaus auf eigenen Arbeiten und Erfahrungen fußende Studie.

Für den Leser ist diese Handreichung eine interessante Quelle über den Stand der aktuellen hydrologischen Forschung - zum Teil mit überraschenden Ergebnissen (ökologische Durchgängigkeit, Grundwasser und Obstbau in Südtirol) oder geographischen Hintergrundinformationen (China, Zentralasien) -, aber auch Anregung für eigene Arbeit und Forschung. Eine Methodenanleitung ist sie allerdings nicht. Die Arbeitsmethodik oder die Beherrschung der Modellierungsschritte müsste man sich entweder aus den detaillierten Ergebnissen der Projektstudien oder aus allgemeinen Methodenanleitungen aneignen.

Herwig WAKONIGG (Graz)

\section{Ossenbrügge Jürgen, Vogelpohl Anne (Hrsg.) (2014), Theorien in der Raum- und Stadtfor-} schung. Einführungen. Münster, Westfälisches Dampfboot. 350 S., zahlr. Abb. ISBN 978-389691-964-9.

Der Rezensent erinnert sich noch gut an jene Zeiten, in denen der Begriff „Theorie“ in der Geographie ein Unwort war und „theoretisch“ grundsätzlich in der abwertenden Bedeutung von „nicht wirklich“ verwendet wurde. Diese Zeiten sind glücklicherweise längst vorbei, und es hat sich in der Zwischenzeit auch in der Geographie herumgesprochen, dass es nichts Praktischeres gibt als eine viable Theorie. Die Komplexität der Erkenntnisobjekte und die multiparadigmatische Struktur unseres Faches bedingen jedoch, dass die Zahl der für geographische Forschungsfragen nützlichen Theorien stark angestiegen ist. Nicht nur für Studenten, sondern auch für bereits länger in der Forschungspraxis stehende Geographen wird es immer schwieriger, sich eine Übersicht über 
die Breite der gegenwärtig verfügbaren Theorieangebote zu verschaffen. Deshalb war es ein überaus verdienstvolles Unterfangen der Herausgeber, mit dem vorliegenden Sammelband eine Art ,Toolkit bereitzustellen, mit dessen Hilfe sich die Leser einen raschen Überblick über einige jener Theorie verschaffen können, die in der Raum- und Stadtforschung genutzt werden können. Sie akzeptieren dabei ausdrücklich, dass die vorliegenden Theorieansätze konkurrierende Erklärungsmodelle anbieten und dass auch keine einheitliche Gegenstandsbeschreibung vorliegt.

Der Sammelband ist in zwei Bereiche gegliedert. Im ersten Abschnitt steht eine Betrachtung der generellen Theoriediskussion zu Raum und Stadt innerhalb spezifischer Disziplinen im Vordergrund. Beiträge aus Anthropologie, Geographie, Geschichtswissenschaften, Politikwissenschaften, Soziologie sowie Stadt- und Regionalplanung verdeutlichen bei aller Verschiedenheit der jeweiligen fachwissenschaftlichen Traditionen vielfältige Überschneidungen und „parallel verlaufende Entwicklungen“ (S. 11). Die 14 Beiträge im zweiten Teil greifen vertiefend wichtige Begriffe und Basiskonzepte theoretischer Zugänge zur Raum- und Stadtforschung auf und verdeutlichen deren Anwendungsmöglichkeiten. Das Spektrum der behandelten Theorien ist sehr breit, es werden viele der aktuell diskutierten neueren Ansätze beleuchtet. Verdienstvollerweise schließen alle Beiträge mit einem Fazit ab, welches die zentralen Argumente der behandelten Theorie in knapper Form zusammenfasst. Als übergreifende Gemeinsamkeit aller Beiträge des Sammelbandes ist die Auffassung anzusehen, dass Raum und Stadt ,gesellschaftlich produzierte Verhältnisse“ (S. 11) darstellen. Der Band ist zweifellos auch in der Lehre (etwa in Masterseminaren) sehr gut einsetzbar.

Peter WeICHHART (Wien)

\section{RASE Wolf-Dieter (2016), Kartographische Oberflächen: Interpolation, Analyse, Visualisie- rung. Norderstedt, Books on Demand. 326 S., zahlr. Farbabb. ISBN 978-3-7392-0922-7.}

Wolf-Dieter RASE, einer der Pioniere der deutschen Computerkartographie, behandelt in diesem Buch die unterschiedlichsten Aspekte, welche sich im Zusammenhang mit kartographischen Oberflächen ergeben, wobei er sein Augenmerk gleichermaßen auf topographische wie auf immaterielle Oberflächen legt.

Nach einem Exkurs zu Datenmodellen und Geo-Basisdaten gibt der Autor zunächst einen Überblick über verschiedene Interpolationstechniken, wobei sowohl Methoden für regelmäßige Punktgitter ([modifizierte] Shepard-Interpolation, Kriging, Spline-Interpolation) als auch für TINs besprochen werden. Erläuterungen betreffend die pyknophylaktische Interpolation sowie Trend-Oberflächen runden diesen ersten Teil des Buches inhaltlich ab. Einen zweiten thematischen Schwerpunkt bilden die Ausführungen zur Beschreibung kartographischer Oberflächen durch deren charakteristische Punkte, Linien und Flächen sowie zur Oberflächengeneralisierung, wobei in diesem Kontext ausschließlich numerische Verfahren zur Datenreduktion behandelt werden. In einem dritten Teil beschäftigt sich der Autor ausführlich mit Fragestellungen im Zusammenhang mit der kartographischen Visualisierung, wobei er hierbei nicht nur elementare Inhalte wie die graphische Semiologie, Isolinien- oder Isoplethenkarten sowie unterschiedliche Beleuchtungsmodelle thematisiert, sondern darüber hinaus auch die Darstellung mittels wertproportionaler Zeichen, die perspektivische Darstellung sowie Stereogramme. Von besonderem Interesse dürfte für viele auch das Kapitel betreffend reale 3D-Modelle sein, in welchem vollkommen neuartige und zukunftsweisende Techniken wie 3D-Drucker besprochen werden.

Wolf-Dieter RASEs jahrzehntelange Berufspraxis gekoppelt mit seiner ebenso langen wissenschaftlichen Tätigkeit ließen ein Buch entstehen, welches in theoretischer wie auch in praktischer Hinsicht in mehreren Punkten besticht, deren wichtigste zweifelsohne die folgenden sind: (a) sämt- 
liche theoretische Ausführungen werden anhand von praktischen Beispielen erläutert sowie durch eine Vielzahl von Graphiken veranschaulicht; (b) die theoretischen Grundlagen werden dem Leser in einer mathematisch informellen, jedoch exakten Weise nähergebracht; der an Mathematik weniger Interessierte wird auf diese Weise nicht unnötig überfordert, für den mathematisch Interessierten finden sich als Ergänzung die entsprechenden Hinweise auf die Primärliteratur; (c) es werden ausschließlich Algorithmen beschrieben, welche nicht eigenständig programmiert werden müssen; man findet ihre Realisierung einerseits in Standard-Paketen wie ArcGIS for Desktop (inklusive der zugehörigen Erweiterungen 3D Analyst, Geostatistical Analyst und Spatial Analyst) oder Surfer, andererseits aber auch in leicht zugänglicher Freeware oder in Open-Source-Programmen.

Resümierend lässt sich festhalten, dass Wolf-Dieter RASE mit seinem Buch den Versuch unternimmt, dem GIS-Anwender einige jener Methoden näherzubringen oder zu erklären, welche sich hinter den unterschiedlichen Optionen vorhandener Programmpakete zu Geo-Informationssystemen und zur Computergraphik verbergen. Aus diesem Grund sollte sein Buch auch in keiner Bibliothek eines GIS-Praktikers sowie eines an Kartographie Interessierten fehlen.

Gert W. WOLF (Klagenfurt a.W.)

RiEDL Helmut (2016), Geographie und Mythos in der Landeskunde Niederösterreichs. Wiener Neustadt, Selbstverlag H. Riedl. 122 S., 25 z.gr.T. farbige Abb. ISBN 978-3-9519882-4-5.

Der emeritierte Salzburger Ordinarius legt erneut eine Arbeit über die Beziehungen zwischen Mythos und Geographie vor. Mit dieser Thematik beschäftigt sich H. RIEDL seit langem (vgl. RIEDL 1986, 1989, 2010, 2015). Er hat mit diesen Arbeiten auch einen neuen Forschungszweig, die „Mythogeographie“, begründet.

Unter Bezugnahme darauf analysiert RIEDL im vorliegenden Band den mythologischen Gehalt ausgewählter Sagen aus Niederösterreich. Zuvor jedoch widmet er ein Kapitel der Beziehung Geographie - Landeskunde (S. 7-25). Der Landeskunde ist RIEDL u.a. durch seine langjährige Mitgliedschaft im Verein für Landeskunde von Niederösterreich und Wien verbunden.

Im Einleitungskapitel wird zunächst aufgezeigt, welche Beiträge zur Landeskunde von Geographen, beginnend mit A. Penck, geleistet wurden: genannt werden u.a. dessen Schüler N. Krebs, E. Oberhummer, A. Becker und H. Hassinger. Als letzter großer Beitrag wird der von E. Arnberger betreute „Atlas von Niederösterreich und Wien“ (1951-1958) bezeichnet. Danach ging laut RIEDL die „klassische Ära der Geographie“ und ihre jahrzehntelange Beziehung zur Landeskunde allmählich zu Ende, denn durch den „Zerfall des Einheitsparadigmas“ der Geographie wurde es ab den 1960er Jahren „schwierig, diese Art von gespaltener Landschaft landeskundlich in Wert zu setzen“ (S. 18). RIEDL nennt die wenigen geographischen Beiträge in jüngeren Publikationen des Vereins für Landeskunde von Niederösterreich und Wien und beschließt das Kapitel mit einem Plädoyer „,ür ein bestimmtes Maß geographischer Landeskunde“, unter Verweis darauf, dass in einer globalisierten Welt lokale und regionale Bezugsrahmen wieder an Bedeutung gewinnen.

Der Hauptteil des Bandes (S. 25-90) enthält, nach Erläuterung der Methodologie der Mytheninterpretation und der Begründung des Mythos-Charakters von Sagen, fünf ,mythogeographische Fallstudien“ aus Niederösterreich: die Sagen von der Bodenwiese (am Schneeberg), vom Gösing bei Sieding, vom Pfennigstein bei Mödling, von den Höhlen im Großen Otter und vom Agnesbründl bei Wien. Es werden jeweils die Beziehungen der Sagen zum Naturraum, zu archetypischen Aussagen des Mythos und zur Geschichte aufgezeigt. Die Erklärungen basieren auf der integrierten Zusammenschau von eigenen Geländeuntersuchungen, mythenwissenschaftlichen und historischen Quellen (vgl. Literaturverzeichnis, S. 92-105). 
Auch wenn man der mythogeographischen Sichtweise des Autors nicht folgen möchte, zeigt der Band auf, welch vertieftes Verständnis von Natur- und Kulturphänomenen aus einer allseitigen geographischen und kulturhistorischen Bildung zu gewinnen ist. Darüber hinaus bilden die Ausführungen des ersten Teils für alle, denen Landeskunde am Herzen liegt, eine Pflichtlektüre.

\section{Zitierte Literatur:}

RIEDL H. (1986), Beiträge zur Beziehung Mythos - Geographie und zur Historischen Geographie von Seriphos (Kykladen). In: Salzburger Exkursionsberichte, 10, S. 7-50.

RIEDL H. (1989), Beiträge zur Beziehungsanalyse von Mythos und Geographie. In: Mitteilungen der Österreichischen Geographischen Gesellschaft, 131, S. 77-92.

RiEDL H. (2010), Mythogeographie. Ein Versuch an Hand kykladischer Fallstudien (= Salzburger Geographische Arbeiten, 47). Salzburg, Selbstverlag des Fachbereichs Geographie und Geologie der Universität Salzburg.

RIEDL H. (2015), Beiträge zur Mythogeographie und Geomorphogenese der Athener Landschaft. Wiener Neustadt, Selbstverlag H. Riedl.

Albert HOFMAYER (Wien)

Droвesch Werner (Hrsg.) (2013), Kärnten am Übergang von der Agrar- zur Industriegesellschaft. Fallstudien zur Lage und Leistung der Landwirtschaft auf der Datengrundlage des Franziszeischen Katasters (1823-1844) (= Geschichtsverein für Kärnten, Aus Forschung und Kunst, 40/1). Klagenfurt, Geschichtsverein für Kärnten. 224 S., 39 Tab., 40 z.T. farbige Abb. ISBN 978-3-85454-126-4.

Rumpler Helmut (Hrsg.) (2013), Der Franziszeische Kataster im Kronland Kärnten (18231844) (= Geschichtsverein für Kärnten, Aus Forschung und Kunst, 40/2). Klagenfurt, Geschichtsverein für Kärnten. 372 S., 46 Karten, 13 farbige Abb. ISBN 978-3-85454-126-4.

RumPler Helmut, Scharr Kurt (Hrsg.) (2015), Der Franziszeische Kataster im Kronland Bukowina/Czernowitzer Kreis (1817-1865). Statistik und Katastralmappen (= Veröffentlichungen der Kommission für Neuere Geschichte Österreichs, 112). Wien - Köln - Weimar, Böhlau. 210 S., 41 Karten, 26 Tab., 54 z.T. farbige Abb. ISBN 978-3-205-79698-5.

Die Grundsteuer zählt zu den ältesten öffentlichen Abgaben. Da bis zur Industrialisierung die Agrarwirtschaft der dominierende Wirtschaftszweig war, galt sie als sichere und ertragreiche Einnahmequelle des Staates. Hauptziel des mit Grundsteuerpatent Kaiser Franz I. vom 23. Dezember 1817 angeordneten Franziszeischen Katasters war es, eine einheitliche Basis für die gleichmäßige Besteuerung aller Grundstücke der „deutschen und italienischen Provinzen“ nach dem theoretischen Reinertrag zu schaffen. Nach dem Vorbild des ersten auf wissenschaftlicher Grundlage beruhenden „Mailänder Katasters“ (1718-1760) wurde dem Kataster eine kartographische Erfassung (Mappierung) zugrunde gelegt. Alle Parzellen wurden auf geodätischer Grundlage (Triangulierung) im Messtischverfahren vermessen und für jede Katastralgemeinde in einer eigenen Katastralmappe dargestellt. Daraus ermittelte man die Grundflächen. In Grund- und Bauparzellenprotokollen wurden die Besitzer festgehalten und die Parzellen nach Kulturgattungen und ihrer Ertragsfähigkeit erfasst.

Der Franziszeische Kataster war der erfolgreiche Versuch, in der Habsburgermonarchie erstmals einen einheitlichen Rechtsraum im Hinblick auf Bodenbewertung und Steuerwesen herzustellen. Dabei zielte dieses System auf den gesamten Länderkomplex der Monarchie und gilt als zentraler Schritt zur ökonomischen Modernisierung. 
Mit dem Franziszeischen Kataster wurde - in bewusster Abkehr vom Konzept der Nationalstaaten - ein wichtiger Schritt gesetzt, um eine Großregion wirtschaftlich, administrativ und rechtlich im Sinn eines zentralstaatlich angestrebten Unum Totum neu zu gestalten. Der Franziszeische Kataster wurde für die staatliche Verwaltung zur Grundsteuer(bemessung) sowie zur Wahrung der Eigentumsrechte eine unentbehrliche Grundlage und Basis für eine einheitliche Rechtskultur in den Ländern der Monarchie.

In dieser seiner politisch-gesamtstaatlichen Bedeutung ist der Kataster seitens der Forschung wenig beachtet worden, er findet daher auch in den Darstellungen zur österreichischen Verwaltungs-, Wirtschafts- und Sozialgeschichte kaum Berücksichtigung. Die fehlende Erschließung des Katasters als Quelle für vergleichende Studien ist ein Manko, dessen Behebung der Forschung neue Impulse verleihen soll.

Die vorliegenden Publikationen sind das Ergebnis des Forschungsprojekts „Der Franziszeische Kataster als Quelle zur Wirtschafts-, Sozial- und Umweltgeschichte in der Startphase der Industriellen Revolution. Edition, Quellenanalyse und Auswertung. Pilotstudien Kärnten und Bukowina“, das von den Universitäten Klagenfurt und Innsbruck sowie der Kommission für Geschichte der Habsburgermonarchie der Österreichischen Akademie der Wissenschaften gemeinsam durchgeführt wurde. Als Forschungsfelder werden im Projekt neben der zentralen Agrargeschichte die Verwaltungs-, Ernährungs- und Klimageschichte, die Flur- und Ortsnamenforschung, die Siedlungs- und Verkehrsgeschichte, die historische Demographie sowie die Ökologie genannt.

Die Kärnten betreffenden Ergebnisse wurden 2013 in zwei umfangreichen Teilbänden herausgebracht: „Kärnten am Übergang von der Agrar- zur Industriegesellschaft“ und dem Editionsband „Der Franziszeische Kataster im Kronland Kärnten“.

Die „Fallstudien zur Lage und Leistung der Landwirtschaft auf der Datengrundlage des Franziszeischen Katasters" enthalten Beiträge von 18 Forschern zur Entstehungsgeschichte des Katasters, seinem historischen Quellenwert für wirtschaftliche, sozialgeschichtliche, kulturelle und verwaltungsgeschichtliche Themenstellungen sowie der rechtlichen und ökonomischen Lage der Bauern am Anfang des 19. Jhs.

Der Editionsband Kärnten ist eine Fundgrube an Daten und enthält nach einigen grundlegenden Einleitungen zur Katastralvermessung und Landesbeschreibung Überblickskarten aller Steuerbezirke, Themenkarten zur Bevölkerungs- und Agrarstruktur, Verzeichnisse aller Ortschaften und Flurnamen (in der damals üblichen deutsch- und slowenischsprachigen Form), zu den Grundherrschaften etc. Die der Publikation beiliegende DVD enthält Überblickskarten aller 809 Katastralgemeinden Kärntens im Gebietsstand vor 1919, Detailkarten ihrer Hauptorte und statistische Daten aus den jeweiligen Schätzungsprotokollen.

Die 1775 unter Josef II. okkupierte Bukowina [Bukovina, Bucovina] war zunächst Teil des Königreichs Galizien-Lodomerien und wurde 1849 als Herzogtum Bukowina ein selbstständiges Kronland. Einer der Hauptgründe für die Entscheidung, die Bukowina neben Kärnten für eine Pilotstudie auszuwählen, war für die Herausgeber die Unvollständigkeit des Katasterwerks in dieser Region und die sich daraus ergebenden Schwierigkeiten sozioökonomischer Vergleiche mit anderen Ländern. Wegen des Widerstandes gegen die Ertragsschätzungen unterblieben diese in der Bukowina, der geplante Stabile Kataster kam nicht zustande. „Das Land der Multikulturalität und Wunderland der mehrsprachigen Literatur mit seiner Hauptstadt Czernowitz [Černìvci] verweigerte sich zunächst, das zeigt die Geschichte des Franziszeischen Katasters, dem mit der Parzellenvermessung und Ertragsschätzung versuchten Schritt zur Modernisierung." Die wechselvolle Geschichte der Bukowina und deren Teilung zwischen Rumänien und der Ukraine stellt auch besondere Anforderungen an die Suche nach den einschlägigen Unterlagen des Franziszeischen Katasters. 
Die Publikation Bukowina enthält neben einführenden Beiträgen zur sozioökonomischen Gesamtsituation der Bukowina im Vormärz, zum politischen Kampf um den Kataster in der Bukowina, zur Stadtentwicklung im Spiegel der Katastralmappen und zur Entwicklung des ländlichen Raumes Überblickskarten aller Steuerbezirke, Themenkarten zur Bevölkerungs- und Agrarstruktur sowie Verzeichnisse aller Katastralgemeinden, Ortschaften und Riednamen.

Die beiliegende DVD bietet Überblickskarten aller 317 Katastralgemeinden der Bukowina, Detailkarten ihrer Hauptorte und statistische Daten aus den jeweiligen Schätzungsprotokollen.

Der Franziszeische Kataster war in seiner Zeit auch im europäischen Vergleich eine bedeutende Kulturleistung. Er schuf für die politisch, ökonomisch und kulturell vielgestaltigen Länder der Monarchie einheitliche Bewertungsstandards auf der Grundlage einer exakten Vermessung. Dem Ziel, den „Franziszeischen Katasters in einer Quellenedition auf breiter sozio-ökonomischer Basis für die weitere Forschung erstmals systematisch aufzubereiten“, werden die drei Bände in hervorragender Weise gerecht. Die Publikationen kommen auch gerade rechtzeitig vor dem zweihundertsten Jahrestag des Grundsteuerpatents, das Kaiser Franz I. am 23. Dezember 1817 erlassen hat.

Christoph Twaroch (Wien) 